\title{
Influence of the initial sludge characteristics and acclimation on the long- term performance of double-compartment acetate-fed microbial fuel cells
}

\author{
Fabrizio Vicari $^{\mathrm{a}}$, Yeray Asensio ${ }^{\mathrm{b}}$, Carmen María Fernandez-Marchante $^{\mathrm{b}}$, Justo Lobato ${ }^{\mathrm{b}}$, \\ Pablo Cañizares ${ }^{\mathrm{b}}$, Onofrio Scialdone ${ }^{\mathrm{a}}$, Manuel Andrés Rodrigo ${ }^{\mathrm{b}, *}$ \\ ${ }^{a}$ Universita degli Studi di Palermo, Dipartimento di Ingegneria Chimica, Gestionale, Informatica, Meccanica, Viale delle Scienze, Palermo, Italy \\ ${ }^{\mathrm{b}}$ University of Castilla-La Mancha, Faculty of Chemical Sciences \& Technologies, Chemical Engineering Department, Avenida Camilo José Cela, 12, 13071 Ciudad Real, \\ Spain
}

\section{A R T I C L E I N F O}

\section{Keywords:}

Double-compartment microbial fuel cells

Start-up

Inoculation

Acclimation

\begin{abstract}
A B S T R A C T
In this work, three double-compartment MFCs (DC-MFC) were operated for 1 month in order to compare their performances in terms of wastewater treatment capacity and electricity production and to get information about how this performance is influenced by the start-up procedure. To do this, they underwent different start-up procedures. One of them (aerobic-starved MFC) was inoculated with 100\% fresh aerobic sludge, another (anaerobic-starved MFC) using 100\% fresh anaerobic sludge, and finally a third one (aerobic-fed MFC) was inoculated using a mixture $10 \%$ fresh aerobic sludge and $90 \%$ synthetic wastewater (based on acetate). Then, from this start-up, the cells were operated exactly under the same feeding and operation conditions and they underwent the same tests. Results demonstrate that after one month of operation, in DC-MFCs, there are no significant differences in the steady state operation conditions reached because the three cells lead to a very similar treatment capacity, quantified in terms of the COD consumption rate, and to a quite similar value of the current produced. A comprehensive electrochemical characterization informed that the small differences cannot be explained in terms of the different start-up period. This means that the DC-MFC technology is robust enough regarding the inoculation and within systems undergoing the same disturbances, outputs obtained are quite the same, which becomes a very important observation for future works.
\end{abstract}

\section{Introduction}

In the last decade, research activity on microbial fuel cell (MFC) technology has increased markedly. These devices consist of electrochemical reactors directly generating electricity from an organic fuel using microorganisms [1-5]. Several advantages in developing this technology could be found, as the production of carbon neutral energy in a World concerned by the high pollution levels that are leading to a global warming, and the wastewater treatment capacity of these bioelectrochemical reactors using wastewater as biofuel [6-10]. However, not enough output energy has been obtained for practical applications and a lot of fundamental work must be done to solve this important issue $[11,12]$. Many inputs have been found to affect the obtained energy by MFCs, being the electrode material one of the most important [13-16]. Among them, carbon based electrodes are the most widely used due to its high conductivity, chemical stability and biocompatibility, which make them suitable for microorganism growth on the electrode surfaces [17-19]. On the other hand, acclimation stage should not be underestimated, because this fundamental stage affects the development of electroactive bacteria that leads to high output power that are necessary to improve the electrical capacity of MFCs [20].

In the literature, it can be found that aerobic and anaerobic sewage sludge are used as initial inoculum for MFCs, because they are easy to obtain and also because they contain a wide range of microorganism cultures, in which many of them are able to directly produce energy oxidizing the organic matter contained in a fuel [21]. Nevertheless, to maximize the energy output obtained, the growth of electroactive bacteria should be favored, while fermentative and methanogens must be inhibited, not only in order to increase the electric efficiency of MFCs, but also, and more important, in order to avoid the attachment of non-electroactive bacteria on the electrode surface, which are unable to produce an electric current during the operation time.

To enhance the growth of electroactive bacteria in the anode compartment, different methods have been studied, such as adding an inhibitor of the methanogenic activity [22-24], the replacement of an electrode biofilm inoculated with a pure microorganism culture $[24,25]$

\footnotetext{
* Corresponding author.

E-mail address: Manuel.Rodrigo@uclm.es (M.A. Rodrigo).
} 
or the microorganism acclimation using different chemical mediators [26]. However, these methods, that have greatly enhanced the electric efficiency of MFC, could not be easily implemented when scaling up is needed. The use of chemical mediators could affect the sustainability of the process, while the use of pure cultures of microorganism could greatly increase the operational costs of the technology.

With this background, the aim of this work has been to study wastewater treatment capacity and electric performance during the start-up period and early stages of three reactors inoculated with different acclimation procedures, using 100\% fresh aerobic sludge, $100 \%$ fresh anaerobic sludge, and 10\% fresh aerobic sludge and $90 \%$ synthetic wastewater (based on acetate) [27-29]. These strategies were focused to meet necessary requirements of readiness and affordability, in a scale-up perspective.

\section{Material and Methods}

\subsection{Inoculation and acclimation}

Scope of this work is to determine the influence of first days of operation on MFC performance. For this purpose two different strategies were established. The first one, here reported as "Starving procedure", is accomplished filling the anodic reservoir with the sludge of a municipal wastewater treatment plan (Ciudad Real WWTP, Castilla-La Mancha, Spain) without any carbon source for 3 days. This strategy was applied to two cells with different inoculum source: the 1st cell was inoculated with secondary decanter sludge of a conventional activated sludge process, the 3rd with anaerobic digester sludge. For the second strategy, "Fed procedure", a small amount of sludge $(10 \mathrm{~mL})$ was put into the reservoir along with a large amount of carbon: the synthetic wastewater described below $(90 \mathrm{~mL})$, for the details see Table1.

MFCs of this work were started according to three different procedures here explained (Table 1). The first and the third were identical but with a different source of inoculum: sludge from the secondary decanter after the activated sludge unit for the 1st, and from the anaerobic digester for the 3rd. The 'starving' procedures are characterized by the absence of an external electron source for the first 3 days, while the 'Fed' one received a large amount of carbon yet the first day. In this last procedure, the amount of sludge inoculated is much less than the 1 st and 3rd.

The synthetic wastewater used to feed the reactors also contained: $\mathrm{NaCH}_{3} \mathrm{COO} 12 \mathrm{~g} \mathrm{~L}^{-1}, \mathrm{NaHCO}_{3} 2.77 \mathrm{~g} \mathrm{~L}^{-1},\left(\mathrm{NH}_{4}\right)_{2} \mathrm{SO}_{4} 1.85 \mathrm{~g} \mathrm{~L}^{-1}$, $\mathrm{KH}_{2} \mathrm{PO}_{4} 1.11 \mathrm{~g} \mathrm{~L}^{-1}, \mathrm{MgCl}_{2} 0.92 \mathrm{~g} \mathrm{~L}^{-1}, \mathrm{CaCl}_{2} 1.25 \mathrm{~g} \mathrm{~L}^{-1},\left(\mathrm{NH}_{4}\right) \mathrm{Fe}\left(\mathrm{SO}_{4}\right)_{2}$ $0.07 \mathrm{~g} \mathrm{~L}^{-1}$. The complete characterization of the solution fed is reported in Table 2. The catholyte was a $\mathrm{pH} 3 \mathrm{HCl}$ solution. All reagents were bought from Sigma-Aldrich, and the water used was Milli-Q grade.

\subsection{Cell assembly and operation}

Three two compartment MFCs were made as described elsewhere [10]. Briefly, two cylindrical chambers of $4 \mathrm{~cm}^{3}$ were realized into $15 \times 15 \times 3 \mathrm{~cm}$ pieces of high density laminate (HDL). Chambers
Table 2

Complete characterization of the synthetic wastewater used during the whole experiment. Analysis of three different batches along with standard deviation.

\begin{tabular}{ll}
\hline \multicolumn{2}{l}{ Synthetic wastewater characterization } \\
\hline pH (Anodic) & $7.36 \pm 0.36$ \\
Conductivity [mS] & $16.10 \pm 0.09$ \\
Suspended Solids $\left[\mathrm{g} \mathrm{L}^{-1}\right]$ & $1.89 \pm 0.08$ \\
TC $\left[\mathrm{mg} \mathrm{L}^{-1}\right]$ & $2971 \pm 112$ \\
$\mathrm{IC}\left[\mathrm{mg} \mathrm{L}^{-1}\right]$ & $192 \pm 29$ \\
Total N $\left[\mathrm{mg} \mathrm{L}^{-1}\right]$ & $1.29 \pm 1.82$ \\
TOC $\left[\mathrm{mg} \mathrm{L}^{-1}\right]$ & $2779 \pm 141$ \\
COD $\left[\mathrm{mg} \mathrm{L}^{-1}\right]$ & $7810 \pm 57$ \\
\hline
\end{tabular}

housed two identical carbon felt (Sigracell ${ }^{\circledR}$ GFA6EA) of $3 \mathrm{~cm}^{2}$ of projected surface as cathode and anode. A Sterion ${ }^{\circledast}$ proton exchange membrane (PEM) sandwiched between two silicon gaskets separated these chambers. Assembled cells had less than $1 \mathrm{~cm}$ of electrode spacing. Electrodes were connected with stainless-steel wires through a $120 \Omega$ external resistance. Every chamber had an inlet and an upper outlet connected to a $100 \mathrm{~cm}^{3}$ reservoir. Here the flow was forced by a peristaltic pump (PD 5001, Heidolph ${ }^{\mathrm{TM}}$ ) running at about $2 \mathrm{~mL} \mathrm{~min}^{-1}$. Reservoirs housed a third port for sampling and media exchange. For anolyte, after acclimation procedure described above, this operation was performed daily in a semi-continuous regimen of 3 days hydraulic retention time (HRT). Catholyte instead was changed daily and the reservoir incorporated an air diffusor which delivered atmospheric air provided by a fishery compressor at $1.6 \mathrm{~L} \mathrm{~min}^{-1}$.

\subsection{Chemical characterization}

Cathodic oxygen consumption was measured with a senION $^{\mathrm{tm}}+$ DO6 (Hatch) dissolved oxygen meter. Conductivity was measured with a GLP 31 (Crison) connected to a 5292 (Crison) probe. A pH 25 (Crison) meter connected to a 5050 (Crison) probe was used to measure the $\mathrm{pH}$. Suspended Solids (SS) were estimated gravimetrically, by evaluating the difference in weight of $0.45 \mu \mathrm{m}$ glass microfiber dried filters (Prat dumas, France), before and after filtering a volume of $10 \mathrm{~mL}$ of re-suspended anodic reservoir bulk solution. Filters were dried for 1 day at $105^{\circ} \mathrm{C}$ in a hoven. Total, Inorganic and Organic carbons were measured with a multi N/C 3100 (Alitik Jena) analyzer. Chemical Oxygen Demand (COD) was evaluated with Spectroquant ${ }^{\circledast}$ COD Cell tests (MERCK) (Sulfuric acid, potassium dichromate, mercury(II) sulfate) for COD range from 500 to $10,000 \mathrm{mg} \mathrm{L}^{-1}$. According to manufacturer instructions, filtered samples $(1 \mathrm{~mL})$ were injected into the test vials and then heated for $120 \mathrm{~min}$ at $150{ }^{\circ} \mathrm{C}$ with an ECO 25 (Velp scientifica) thermoreactor. COD values were obtained after cooling at room temperature with a Spectroquant ${ }^{\circledR}$ Pharo 100 (MERCK) spectrophotometer regularly calibrated. Sludge Volume Index SVI was evaluated filling a graduated cone with $30 \mathrm{~mL}$ of the anodic solution and measuring the volume of the settled solids after $30 \mathrm{~min}$. From this

Table 1

Acclimation procedures applied in this work.

\begin{tabular}{|c|c|c|c|}
\hline \multicolumn{4}{|c|}{ Acclimation procedures } \\
\hline & 1 & 2 & 3 \\
\hline Day $\downarrow$ & Starving aerobic & Aerobic fed & Starving anaerobic \\
\hline $1 \mathrm{st}$ & $\begin{array}{l}100 \mathrm{~mL} \text { total reservoir volume. } 100 \mathrm{~mL} \text { fresh aerobic } \\
\text { sludge ( } 50 \mathrm{~mL} \text { decanted }+50 \mathrm{~mL} \text { supernatant). }\end{array}$ & $\begin{array}{l}100 \mathrm{~mL} \text { total reservoir volume. } 10 \mathrm{~mL} \text { fresh aerobic } \\
\text { sludge (Decanted) }+90 \mathrm{~mL} \text { synthetic wastewater. }\end{array}$ & $\begin{array}{l}100 \mathrm{~mL} \text { total reservoir volume. } 100 \mathrm{~mL} \text { fresh anaerobic } \\
\text { sludge ( } 50 \mathrm{~mL} \text { decanted }+50 \mathrm{~mL} \text { supernatant). }\end{array}$ \\
\hline 2nd & $\begin{array}{l}50 \mathrm{~mL} \text { withdrawn and replenish with fresh aerobic } \\
\text { sludge ( } 25 \mathrm{~mL} \text { decanted }+25 \mathrm{~mL} \text { supernatant). }\end{array}$ & $\begin{array}{l}50 \mathrm{~mL} \text { withdrawn and replenish with synthetic } \\
\text { wastewater. }\end{array}$ & $\begin{array}{l}50 \mathrm{~mL} \text { withdrawn and replenish with fresh anaerobic } \\
\text { sludge ( } 25 \mathrm{~mL} \text { decanted }+25 \mathrm{~mL} \text { supernatant). }\end{array}$ \\
\hline 3rd & As the 2nd. & As the 2nd. & As the 2nd. \\
\hline 4th & \multicolumn{3}{|c|}{ Start of standard feeding with synthetic wastewater at a Hydraulic Retention Time of 3 days ( $33 \mathrm{~mL}$ changed every day). } \\
\hline
\end{tabular}


volume, the corresponding volume for a liter solution was derived and then divided by the value of SS of the same sample defining the SVI.

\subsection{Electrochemical measurements}

Every electrochemical measurement here reported was repeated a minimum of three times during cells stationary phase. Results shown are the average of all the available data. An Autolab AUT84129 galvanostat/potentiostat (Metrohm) controlled with a PC embedding the Nova 1.11 software was used. Cyclic voltammetries were obtained recording the current as a function of the potential in 3 consecutive cycles from -0.6 to $0.3 \mathrm{~V}$ vs SCE, step potential $0.005 \mathrm{~V}$, scan rate $0.005 \mathrm{~V} \mathrm{~s}^{-1}$. Only the second cycles are here reported. Voltammograms were realized extracting the anodic carbon felt electrodes from cells and moving them into a simple electrochemical vessel housing a saturated calomel reference electrode (SCE) and a platinum counter electrode $1.0 \times 1.5 \mathrm{~cm}$. In this case every connection was realized in platinum. The whole system was purged with $\mathrm{N}_{2}$ for at least $15 \mathrm{~min}$ before the operation. A moderate overpressure was maintained all over the experiment and temperature was kept at $25^{\circ} \mathrm{C}$ recirculating water into the external jacket of the cell. Polarization curves and impedance analysis were recorded in three non-consecutive days, 2 times for day. Averaged values were obtained and here reported along with the standard deviation. For the polarization, cells were left on open circuit for at least $2 \mathrm{~h}$, then the potential was varied from the open circuit voltage (OCV) to $0.001 \mathrm{~V}$ with a scan rate of $0.001 \mathrm{~V} \mathrm{~s}^{-1}\left(1 \mathrm{mV} \mathrm{s}^{-1}\right)$ and a step potential of $0.01 \mathrm{~V}$. Power was then calculated as the product of current and voltage. For impedance analysis, potential was set to OCV and varied of a $10 \%$ RMS in range of frequencies from $200 \mathrm{KHz}$ to $200 \mathrm{~Hz}$, 50 frequencies with a logarithmic step. Considering the system as a semi-continuous one, Coloumbic efficiency $\left(\mathrm{C}_{\mathrm{E}}\right)$ has been calculated on a $\triangle$ COD consumption base as (Eq. (1)), where $M=32$ is the oxygen molecular weight, I is the average current, $F=96,485 \mathrm{C} \mathrm{mol}^{-1}$ is the Faraday constant, $b=4$ are the electrons consumed per mole of oxygen, q L s${ }^{-1}$ is the influent flow [30].

$\mathrm{C}_{\mathrm{E}}=\mathrm{MI} / \mathrm{Fbq} \Delta \mathrm{COD}$

\section{Results and discussion}

\subsection{Chemical oxygen demand}

In evaluating a MFC as a bio electrochemical device able to produce an electric current from the oxidation of organic matter, the COD concentration in the outlet of the MFC (effluent) is worth to be evaluated as one important parameter. Fig. 1 shows the COD monitored in the anode effluent of the three different MFCs prepared as reported in Table 1, operated in semi continuous mode, during the long-term operation. COD concentration values stabilized in steady-state values, approximately in the fourth week of operations. Different fluctuations were observed in the last days of operations because of the complexity bio electrochemical reactions that take place in the anode compartment. However, it can be observe in Fig. 1b, how the steady-state values achieved by the different MFCs are pretty similar among them, no matter the inoculation stage used to acclimate the microorganism inoculum. As shown in Fig. 1b, the COD concentration observed in the anode effluent in aerobic-starved MFC was $4550 \mathrm{mg} \mathrm{L}^{-1}$, while $3632 \mathrm{mg} \mathrm{L}^{-1}$ and $3735 \mathrm{mg} \mathrm{L}^{-1}$ COD concentrations were observed in the aerobic-fed MFC and anaerobic-starved MFC, respectively. Observed deviations were plotted in Fig. 1 as well. Attending to this fact, it could be say, that the selected acclimation stage in the first days could not be a critical parameter to the long-term wastewater treatment capacity of double-chamber MFCs. However, it is worth to mention that for more than $800 \mathrm{~h}$, the MFC inoculated with the starving procedure (i.e. with an aerobic sludge that received the organics only after 4 days) gave a lower consumption of organics. This MFC was the one that gave
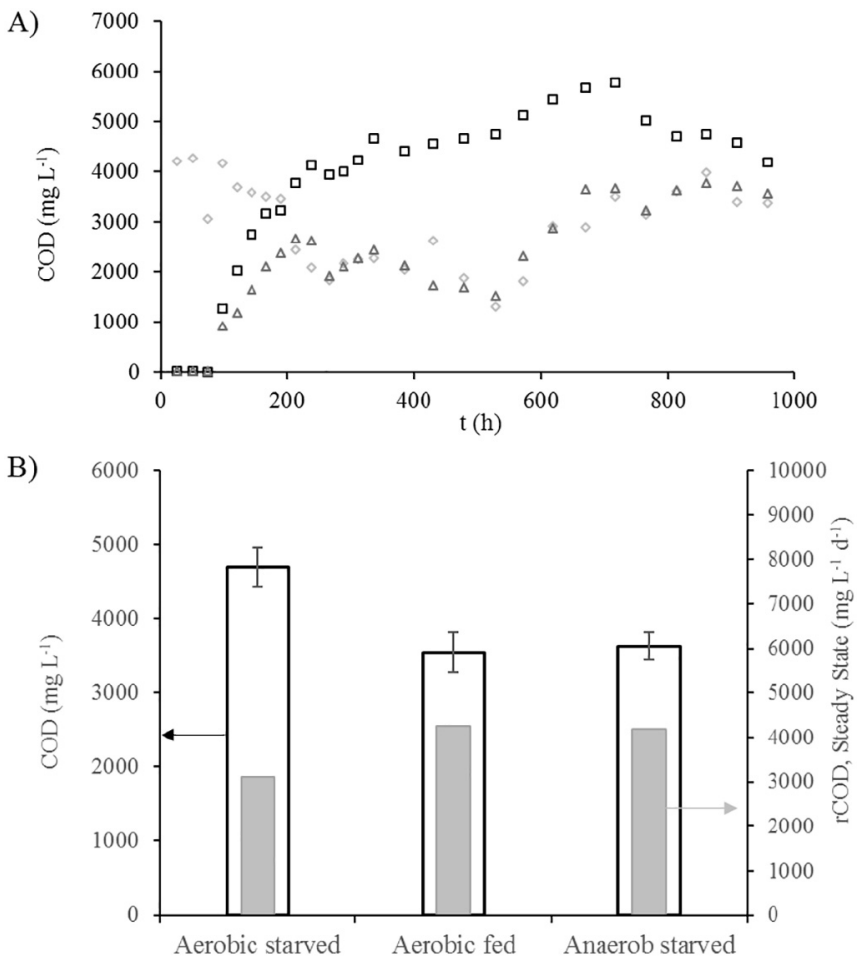

Fig. 1. A) Outlet Chemical Oxygen Demand (COD) in time: $\square$ Aerobic starved, $\checkmark$ Aerobic fed, $\Delta$ Anaerobic starved. B) Averaged COD and COD consumption rate (rCOD) (Grey) during last five days of operation.

more current. Hence, it seems reasonable that this procedure strongly favors exoeletrogenic bacteria (that gives the current) with respect to not-eletrogenic ones (that are more efficient for COD reduction).

Initially, this behavior could be explained attending to the operation conditions, room temperature, fuel composition, HRT, external electric load, that were kept constant for the MFCs during all the experiment. This could lead to the growth of the same microorganism populations, in the formed biofilm and in suspension, that are favored to the selected operation conditions, described in materials and methods section.

\subsection{MFCs current production}

The biological process underlining the functioning of MFCs is not an immediate and/or simple process. There is a competition for substrate consumption between exoelectrogenic and non exoelectrogenic bacteria. In aerobic sludge, these last types of microorganisms are usually more abundant, since the pathways leading to electrode reduction are anaerobic or facultative [31,32]. In anaerobic sludge, a similar competition exists with methanogens population [33], but the anaerobic environment is more selective and houses only species prone to reduce a terminal electron acceptor different from oxygen [34]. This is probably the reason why the first reactor who started producing an appreciable current was that one inoculated with anaerobic sludge. Since the sludge was kept in a forced anaerobic condition for three days, a deeper selection occurred leading probably to the suppression of the methanogens, whose metabolism is slower than exoelectrogens one [35]. When the 4th day an electron donor was introduced into the cell, the remaining community used the electrode as final electron acceptor, leading to an output of $0.31 \mathrm{~A} \mathrm{~m}^{-2}$ when all the other cells were still at $0.05 \mathrm{~A} \mathrm{~m}^{-2}$ (See Fig. 2A). Many facultative bacteria that can be found into aerobic sludge and not into anaerobic, are indeed capable to exchange electrons with an electrodes, as Shewanella sp. [36-37]. For this reason, an appreciable current density is always expected from aerobic sludge once the strong competition for substrate consumption is over. Thus, after $240 \mathrm{~h}$ the current produced by the cell inoculated with 

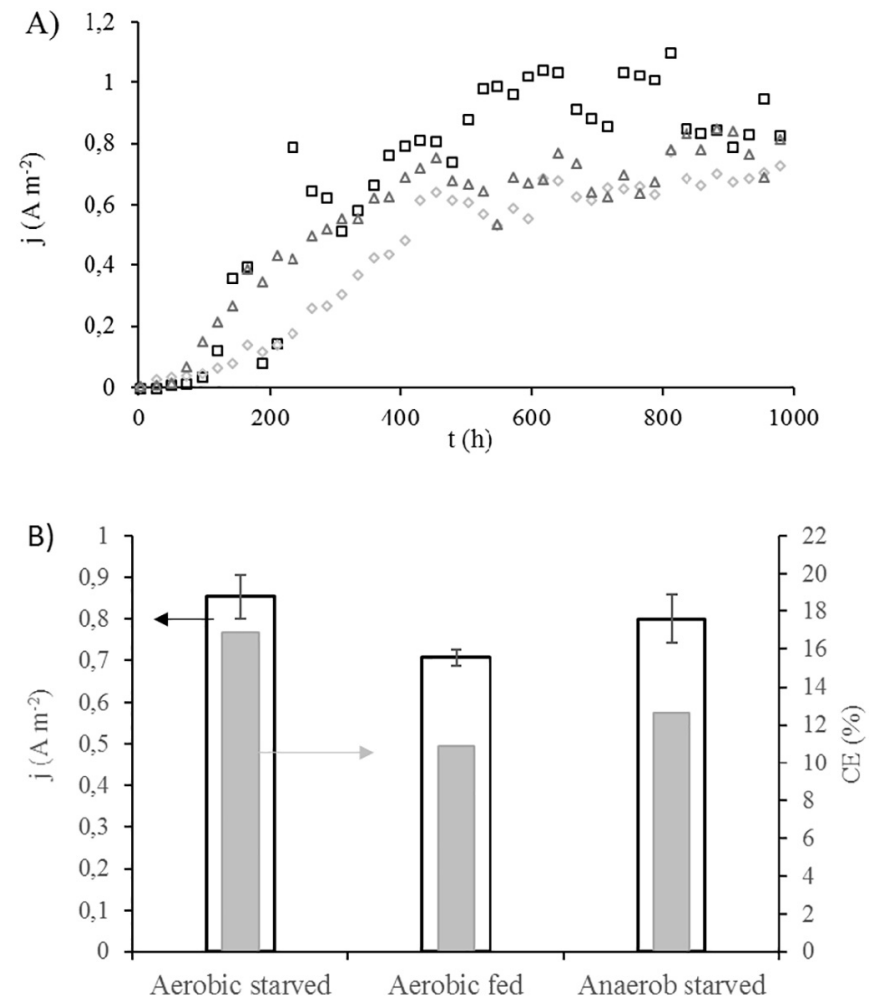

Fig. 2. A) Current density in time: $\square$ Aerobic starved, $\diamond$ Aerobic fed, $\Delta$ Anaerobic starved. B) Averaged current density and Coulombic Efficiency (Grey) during last five days of operation.

aerobic sludge overcome the anaerobic one, recording values always superiors to the others for more than $600 \mathrm{~h}$. In particular, the higher amount of electricity was produced by the MFC inoculated with the aerobic sludge (Fig. 2B). On the other hand, the lower average current
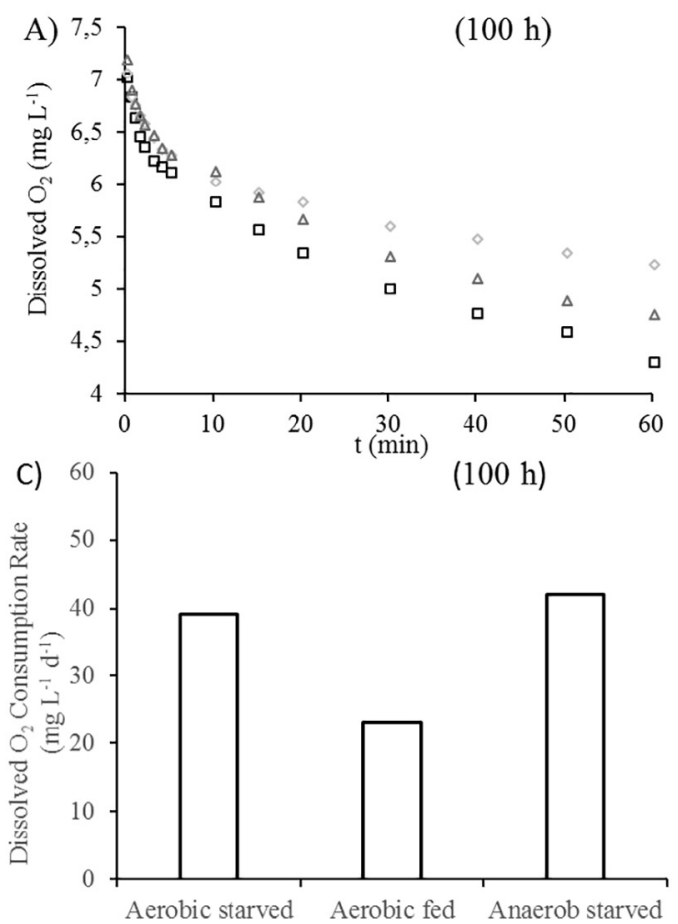

density was produced with the MFC inoculated with an aerobic sludge that received the synthetic wastewater the first day ("aerobic fed") instead of the third one, thus showing that the time of the introduction of the organic can affect the MFC performances. In particular, the slightly less efficient production of the fed inoculum could be explained by the occurrence of the contextual growth of a non electrogenic biofilm on electrode surface.

However, after about $1000 \mathrm{~h}$, all cells leveled off to similar values ranging from $0.67 \mathrm{~A} \mathrm{~m}^{-2}$ of the fed inoculum to $0.85 \mathrm{~A} \mathrm{~m}^{-2}$ of the aerobic (See Fig. 2B), showing that the effect of the inoculum procedure becomes less important with the time passed. Gao et al., 2014 [34] carried out similar studies and identified the microorganisms in the biofilms. This study indicated that aerobic sludge performed better for MFCs start-up, and the enrichment of anodic microbial consortium with different inocula but same substrate resulted in uniformity of functional microbial communities. They concluded that long term acclimation of sludge in MFCS with different inocula but same substrates eventually resulted in uniformity of microbial communities.

\subsection{Cathodic oxygen consumption rate}

The oxygen consumption rate in the cathode compartment of a double-compartment MFC is directly related to the electricity production of MFCs and because of that, the reduction capacity of the bioelectrochemical device could be studied attending to this parameter. This could be easily understood taking into account that electrons supplied for the reduction reaction in the cathode compartment can only be provided by the bioelectrochemical reactions that occurs in the anode chamber.

The reduction capacity of the cathode chamber in a MFC is important, attending to the fact that the oxygen reduction reaction (ORR) is the limiting step in MFC operation. Attending to the fact that carbon felt was used as electrode material for all MFCs, the different values achieved depends of the microorganism populations that are attached to the anode surface electrodes. Dissolved Oxygen (DO) concentration in the cathodic compartment was monitored 100 and $700 \mathrm{~h}$ after the
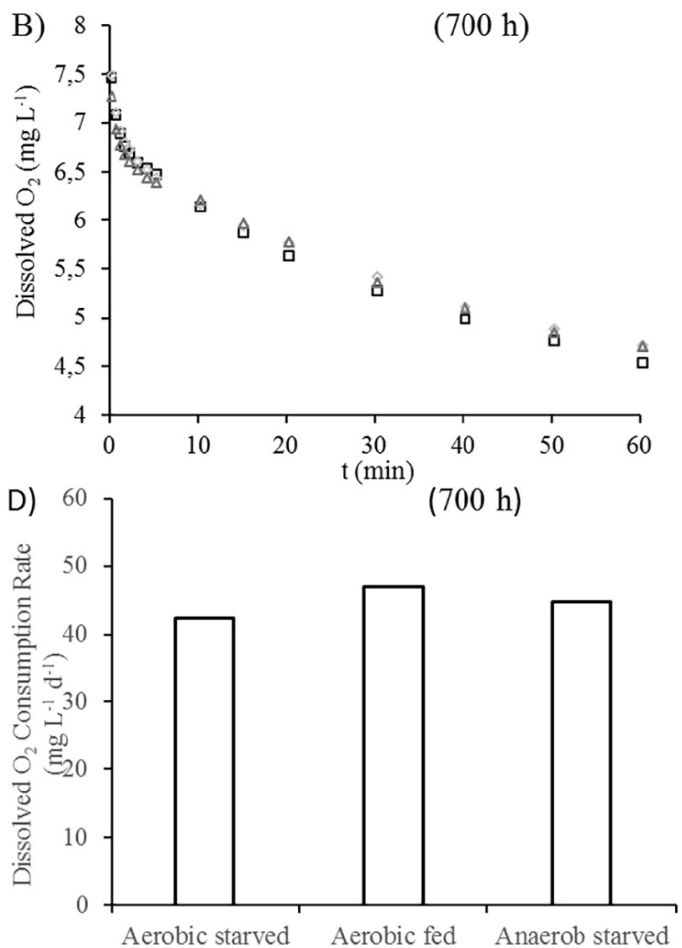

Fig. 3. Cathodic Dissolved Oxygen (DO) concentration (mg L ${ }^{-1}$ ) in the absence of aeration for $\square$ Aerobic starved, $\diamond$ Aerobic fed and $\Delta$ Anaerobic starved reactors, a) $100 \mathrm{~h}$ and b) $700 \mathrm{~h}$ after start-up. DO consumption rate $\left(\mathrm{mg} \mathrm{L}^{-1}\right.$ day $\left.^{-1}\right)$ after c) $100 \mathrm{~h}$ and d) $700 \mathrm{~h}$. 

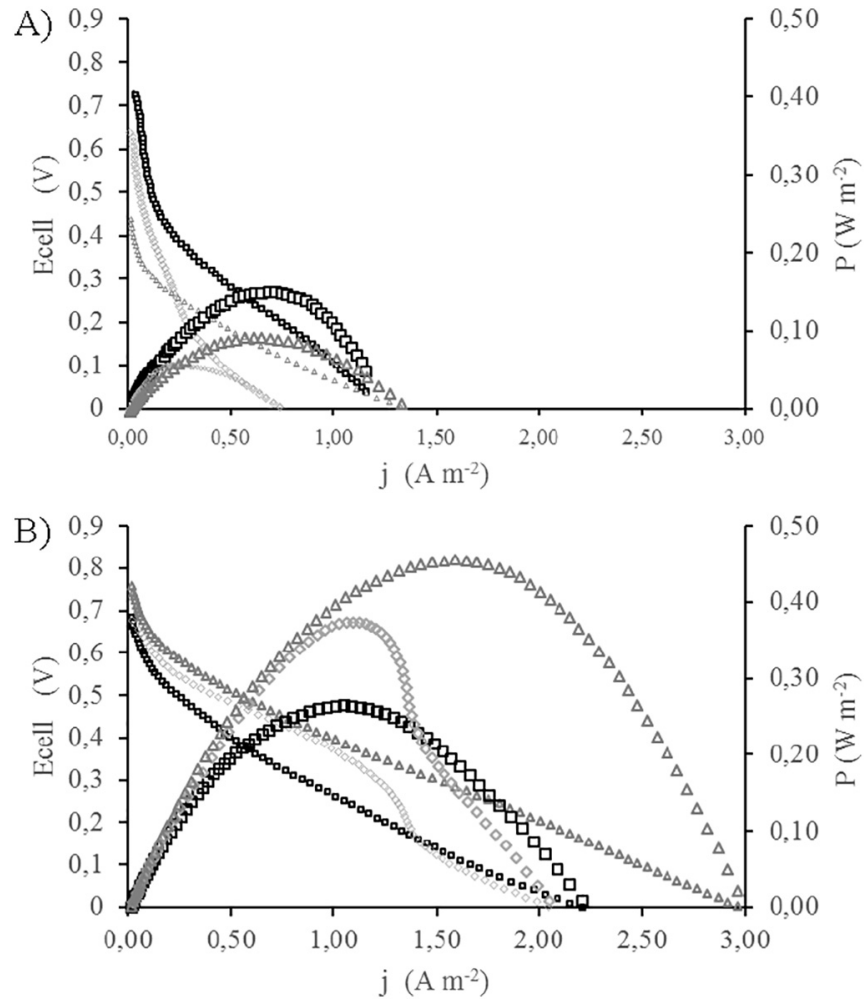

Fig. 4. Power density and polarization curves for $\square$ Aerobic starved, $\diamond$ Aerobic fed and $\Delta$ Anaerobic starved after A) $100 \mathrm{~h}$ and B) $700 \mathrm{~h}$ of operations.

inoculation of the cells, in the absence of aeration for a period of $1 \mathrm{~h}$ (see Fig. 3A and B). Comparing Fig. 3C and D it is possible to see how in the early stages of operation DO consumption rate was already at his maximum for the two starved inocula, while not fully developed for the fed reactor. In steady state conditions (i.e. Fig. 3D) ORR shows the same behavior independently of the selected MFC acclimation. In other words, even if different acclimation steps are selected to run MFCs, double-chamber MFCs shows their robustness in the long-term operation achieving almost the same oxygen reduction reaction efficiency, which could be a key knowledge to decrease the operational costs of this technology in the scale-up.

\subsection{Power density and polarization test}

In order to know more about current produced by the system as a function of the applied potential, linear sweep voltammetries were obtained at $1 \mathrm{mV} \mathrm{s}^{-1}$. In Fig. 4 the averaged curves of 6 different acquisitions operated at the beginning and during steady state are reported. Comparing Figure and Fig. 4B the increase in both power and current densities is clear. Additionally, is worth underlining that, in terms of current density, fed reactor resulted always the less performing. In the stationary phase, MFC inoculated with anaerobic sludge recorded the highest open circuit voltage (OCV) of $762 \mathrm{mV}$ against the $690 \mathrm{mV}$ of the aerobic one and the $679 \mathrm{mV}$ of the fed acclimated one. The internal resistance of the cell can be calculated as the slope of the straight line interpolating the central region of the curves on the $E$ vs $I$ plane. The "fed" reactor was the one with the lowest internal resistance, $804 \Omega$ against the $906 \Omega$ of the anaerobic and the $1248 \Omega$ of the aerobic. A very important observation is that despite the lower ohmic loss was recorded for the aerobic-fed MFC, it did not attain the highest power or current density (see Figure) and overshoot was observed in power curve in the decision curve, this phenomena was attributed to increased internal resistance due to ionic depletion and/or microbial exhaustion [38].
This is because after $1.08 \mathrm{~A} \mathrm{~m}^{-2}$, the power density and the cell voltage decreased markedly up to values above those of the aerobic sludge inoculated reactor. This behavior, that indeed affects the global performance of the cell, can be explained by taking into account that a thicker, interfering biofilm, could lead to a mass transport limitations in both, electron donor to the bacteria and of protons from them than can explain the high loss evidenced in figure [20]. Ieropoulos et al., 2010 studied the effects of inoculum and time on the internal resistance of microbial fuel cells and explained that over time both power and internal resistance increased for the lower flow-rates perhaps explained by and evolving microflora that consequently changed redox potential [38]. The cell inoculated with the anaerobic sludge gave the best power density of $4.59 \mathrm{~W} \mathrm{~m}^{-2}$, corresponding to $1.38 \mathrm{~W} \mathrm{~m}^{-3}$, when the reservoir volume is taken into account. These values are in line with those reported in literature for air-cathode MFCs [39-42], which is indeed a more complicate setup.

\subsection{Cyclic voltammetries analysis}

Cyclic voltammograms (CVs) were performed under turnover conditions, in a fresh media. Under these conditions, all the proteins involved in the respiratory pathways to the electrode surface change their oxidation state continuously, causing meaningful flow of current [40-43]. The scan rate chosen is $5 \mathrm{mV} \mathrm{s}^{-1}$, enough slow to involve all the proteins typically present in electrode respiration. Anodic carbon felts were extracted from operating MFCs and put into a conventional electrochemical batch reactor under an $\mathrm{N}_{2}$ atmosphere. It is known that the use of large porous electrodes [41-44], as those used into our MFCs, can lead to large peaks into the anodic current that can wrongly interpreted as the action of some diffusion limited mediator, but they truly are to be considered as the result of a lack of electron donor into the inner part of the carbon felt [42]. This behavior is apparent in our CVs with different peak potentials ranging from about -0.1 to $0.1 \mathrm{~V}$ vs SCE (See Fig. 5).

Midpoint potentials of the reverse scan are less pronounced and occurred at other locations than the forward scan, pointing to a thick developed biofilm, which of course has a large variety of local inhomogeneity. This analysis revealed indeed that every inoculation was capable to develop a catalytic biofilm. A blank carbon felt was used as a control experiment (Fig. 5 black dots). The current produced in the control experiment was practically zero for every potential explored, while all the colonized ones gave a substantial catalytic current with a zero current potential onset of $-0.45 \mathrm{~V}$. This very same potential is

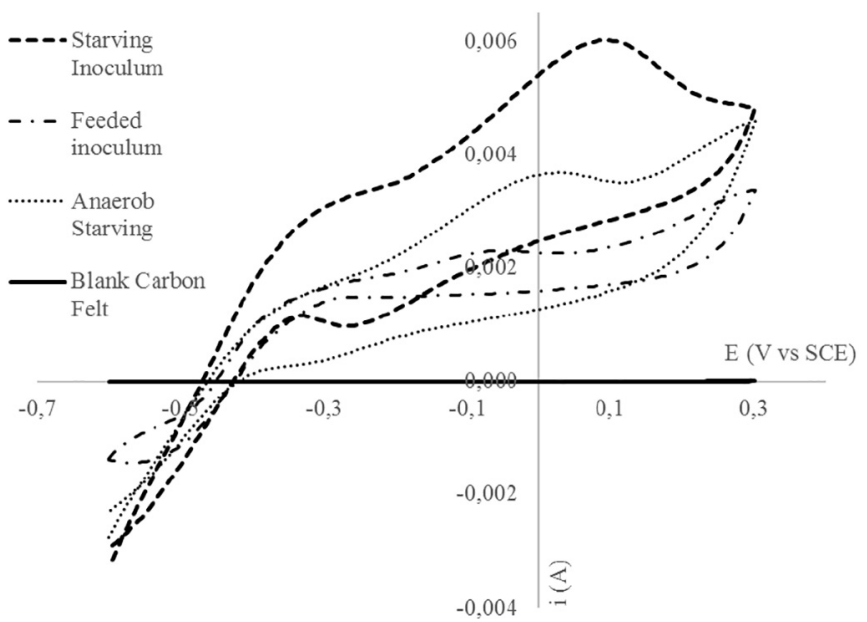

Fig. 5. Cyclic voltammograms of the anodic carbon felts of the 3 cells analyzed in this work: - - - Aerobic starved, - - - Aerobic fed, ....... Anaerobic starved and — blank carbon felt. Synthetic wastewater deoxygenated with $\mathrm{N}_{2}$ for $15 \mathrm{~min}$ before the experiment. SCE as reference electrode. Scan rate of $5 \mathrm{mV} \mathrm{s}^{-1}$. 


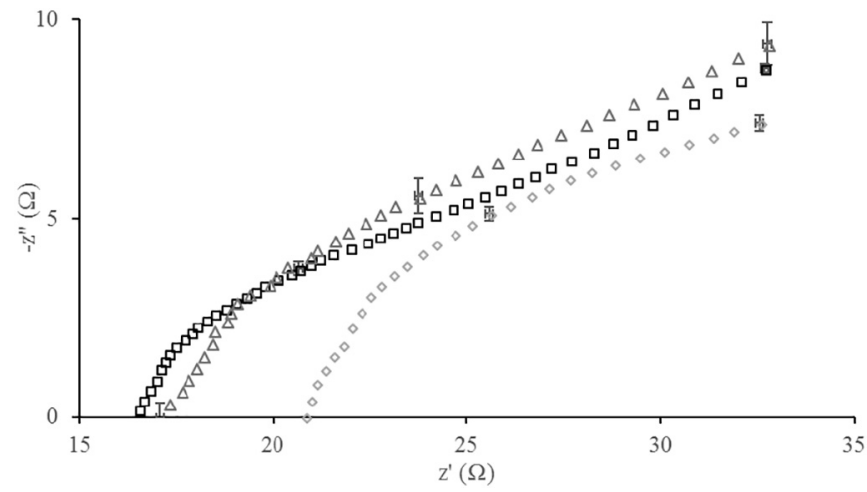

Fig. 6. EIS analysis $\square$ Aerobic starved, $\diamond$ Aerobic fed, $\Delta$ Anaerobic starved.

identical to what achieved by Blanchet et al. [43], despite in that research a stable plateau was obtained after $-0.02 \mathrm{~V}$, while in our case it has never been observed. This increasing trend from $+0 \mathrm{~V}$ to $+0.4 \mathrm{~V}$ can be attributed to the presence of microorganisms like Shewanella sp. which are known to interact with electrodes with two adjacent mechanism: with free flavins compound from $-0.21 \mathrm{~V}$ and with membrane bound cytochromes at higher potentials [44]. Even if every electrode investigated reacts in a similar way, it is to be underlined that the one with aerobic sludge acclimated with starving procedure was capable to give rise to a current of $0.06 \mathrm{~A}$, which is more than what recorded for the same procedure with anaerobic sludge $(0.045 \mathrm{~A})$ or with the fed one $(0.033 \mathrm{~A})$. This result can suggest that the first acclimation procedure was more efficient in order to develop an electroactive biofilm.

\subsection{Electrochemical impedance spectroscopy}

Internal resistance ( $R_{\text {int }}$ ) could be divided in three different parts: a) activation resistance $\left(R_{a c t}\right)$ from bio-electrochemical reactions and charge transfer between the microorganisms attached to the electrode surface and the anode, b) ohmic resistance $\left(R_{\text {ohm }}\right)$ that is caused by the electrode material, membrane and wiring connections, and c) ionic resistance $\left(R_{i o n}\right)$ caused by the proton mass transfer and diffusion $[9,45]$. $R_{\text {act }}$ have been determined potentiostatically using a wide frequency range. Obtained electrical impedance spectroscopies (EIS) for the three different MFCs when the system was stabilized are shown in Fig. 6. However, EIS have been done during the long-term operation but no big differences have been found, deviations bars have been plot in the figure as well.

Attending the activation resistance it can be seen how are quite low, $17 \Omega$ for the aerobic-starved and anaerobic-starved MFCs, and $21 \Omega$ for the aerobic-fed MFC. These results show that the electron transfer from the anode compartment to the cathode compartment is quite high. In addition, as it was said before, the similarity not only in the $R_{\text {act }}$ of the three different cells, but even in the shape of the whole EIS show the robustness of the double-compartment MFC for energy generation, not depending, at least with no high impact, the selected acclimation stage. In both three cases, biofilm was formed and the device was able to produce energy.

\section{Conclusions}

From this work, it can be concluded that the start-up procedure affects the MFC performances, in terms of the wastewater treatment capacity and electricity production, for the first weeks of operations, but the effect becomes very small in long-term operations. In shortterm, the MFC fed with an aerobic sludge gave higher currents. However, under steady-state conditions, both aerobic and anaerobic sludge can be seeded and develop successful bioelectrogenic cultures. Steady-state conditions are reached in less than forty days and the only remarkable observation is that the starving procedure can speed up the selection of exoelectrogenic specimens. Both direct and mediated electron transfer can be observed in the DC-MFC and the impedance analysis unveils a very low internal resistance.

\section{Acknowledgements}

Financial support from the AEI (Agencia Estatal de Investigación) of the Spanish Ministry of Economy and Competitiveness (MINECO) through project CTQ2013-49748-EXP (Explora Program) is gratefully acknowledged.

\section{References}

[1] A.-M. Lakaniemi, O.H. Tuovinen, J.A. Puhakka, Anaerobic conversion of microalgal biomass to sustainable energy carriers - a review, Bioresour. Technol. 13 (2013) 222-231.

[2] F.J. Hernández-Fernández, A. Pérez de los Ríos, M.J. Salar-García, V.M. OrtizMartínez, L.J. Lozano-Blanco, C. Godínez, F. Tomás-Alonso, J. Quesada-Medina, Recent progress and perspectives in microbial fuel cells for bioenergy generation and wastewater treatment, Fuel Process. Technol. 138 (2015) 284-297.

[3] J.B. Davis, H.F. Yarbrough, Preliminary experiments on a microbial fuel cell, Science 137 (1962) 615-616.

[4] I. Gajda, J. Greenman, C. Melhuish, I. Ieropoulos, Self-sustainable electricity production from algae grown in a microbial fuel cell system, Biomass Bioenergy 82 (2015) 87-93.

[5] J. Villaseñor, L. Rodriguez, C.M. Fernández Marchante, F.J. Fernández, M.A. Rodrigo, The salinity effects on the performance of a constructed wetlandmicrobial fuel cell, Ecol. Eng. 107 (2017) 1-7.

[6] B.E. Logan, Simultaneous wastewater treatment and biological electricity generation, Water Sci. Technol. 5 (2005) 31-37.

[7] T. Shimoyama, S. Komukai, A. Yamazawa, Y. Ueno, B.E. Logan, K. Watanabe, Electricity generation from model organic wastewater in a cassette-electrode microbial fuel cell, Appl. Microbiol. Biotechnol. 80 (2008) 325-330.

[8] A. Raschitor, G. Soreanu, C.M. Fernandez-Marchante, J. Lobato, P. Cañizares, I. Cretescu, M.A. Rodrigo, Bioelectro-Claus processes using MFC technology: influence of co-substrate, Bioresour. Technol. 189 (2015) 94-98.

[9] Y. Asensio, C.M. Fernández-Marchante, J. Lobato, P. Cañizares, M.A. Rodrigo, Algal biomass as fuel for stacked MFCs for profitable, sustainable and carbon neutral bioenergy generation, J. Chem. Technol. Biotechnol. 93 (2018) 287-293.

[10] Y. Asensio, E. Mansilla, C.M. Fernández-Marchante, J. Lobato, P. Cañizares, M.A. Rodrigo, Towards the scale-up of bioelectrogenic technology:stacking microbial fuel cells to produce larger amounts of eletricity, J. Appl. Electrochem. (2017) 1118-1125.

[11] P. Aelterman, K. Rabaey, H.T. Pham, N. Boon, W. Verstraete, Continuous electricity generation at high voltages and currents using stacked microbial fuel cells, Environ. Sci. Technol. 40 (2006) 3388-3394.

[12] A. Dekker, A. Ter Heijne, M. Saakes, H.V.M. Hamelers, C.J.N. Buisman, Analysis and improvement of a scaled-up and stacked microbial fuel cell, Environ. Sci. Technol. 43 (23) (2009) 9038-9042.

[13] S. Bebelis, K. Bouzekb, A. Cornellc, M.G.S. Ferreirad, G.H. Kelsalle, F. Lapicquef, C. Ponce de Leóng, M.A. Rodrigoh,*, F.C. Walshga, Highlights during the development of electrochemical engineering, Chem. Eng. Res. Des. 91 (10) (2013) 1998-2020.

[14] C. Prestigiacomo, C.M. Fernández-Marchante, F.J. Fernández-Morales, P. Cañizares, O. Scialdone, M.A. Rodrigo, New prototypes for the isolation of the anodic chambers in microbial fuel cells, Fuel 181 (2016) 704-710.

[15] E.D. Penteado, C.M. Fernández-Marchante, M. Zaiat, E. Gonzalez, M.A. Rodrigo, Influence of carbon electrode material on energy recovery from winery wastewater using a dual-chamber microbial fuel cell, Environ. Technol. 38 (2017) 1333-1341.

[16] Y. Asensio, C.M. Fernández-Marchante, J. Lobato, P. Cañizares, M.A. Rodrigo, Influence of the ion-exchange membrane on the performance of double-compartment microbial fuel cells, J. Electroanal. Chem. 808 (2018) 427-432.

[17] X. Chen, D. Cui, X. Wang, X. Wang, W. Li, Porous carbon with defined pore size as anode of microbial fuel cell, Biosens. Bioelectron. 69 (2015) 135-141.

[18] Y. Asensio, I.B. Montes, C.M. Fernandez-Marchante, J. Lobato, P. Cañizares, M.A. Rodrigo, Selection of cheap electrodes for two-compartment microbial fuel cells, J. Electroanal. Chem. 785 (2017) 235-240.

[19] E.D. Penteado, C.M. Fernández-Marchante, M. Zaiat, E. Gonzalez, M.A. Rodrigo, Energy recovery from winery waswater using a dual chamber microbial fuel cell, J. Chem. Technol. Biotechnol. 91 (2016) 1802-1808.

[20] M.A. Rodrigo, P. Cañizares, H. García, J.J. Linares, J. Lobato, Study of the acclimation stage and of the effect of the biodegradability on the performance of a microbial fuel cell, Bioresour. Technol. 100 (20) (2009) 4704-4710.

[21] L.T. Angenent, S. Sung, L. Raskin, Methanogenic population dynamics during startup of a full-scale anaerobic sequencing batch reactor treating swine waste, Water Res. 36 (18) (2002) 4648-4654.

[22] A. Sotres, L. Tey, A. Bonmatí, M. Viñas, Microbial community dynamics in continuous microbial fuel cells fed with synthetic wastewater and pig slurry, Bioelectrochemistry 111 (2016) 70-82.

[23] L. Zhuang, Q. Chen, S. Zhou, Y. Yuan, H. Yuan, Methanogenesis control using 2 - 
bromoethanesulfonate for enhanced power recovery from sewage sludge in air cathode microbial fuel cells, Int. J. Electrochem. Sci. 7 (7) (2012) 6512-6523.

[24] J.R. Kim, B. Min, B.E. Logan, Evaluation of procedures to acclimate a microbial fuel cell for electricity production, Appl. Microbiol. Biotechnol. 68 (1) (2005) 23-30.

[25] M.R. Miroliaei, A. Samimi, D. Mohebbi-Kalhori, M. Khorram, Kinetics investigation of diversity cultures of E. coli and Shewanella sp., and their combined effect with mediator on MFC performance, J. Ind. Eng. Chem. 25 (2015) 42-50.

[26] T. Song, X. Wu, C.C. Zhou, Effect of different acclimation methods on the performance of microbial fuel cells using phenol as substrate, Bioprocess Biosyst. Eng. 37 (2) (Feb. 2014) 133-138.

[27] E.D. Penteado, C.M. Fernandez-Marchante, M. Zaiat, P. Cañizares, E.R. Gonzalez, M.A. Rodrigo, Influence of sludge age on the performance of MFC treating winery wastewater, Chemosphere 151 (2016) 163-170.

[28] Y. Asensio, C.M. Fernandez-Marchante, J. Lobato, P. Cañizares, M.A. Rodrigo, Influence of the fuel and dosage on the performance of double-compartment microbial fuel cells, Water Res. 99 (2016) 16-23.

[29] E.D. Penteado, C.M. Fernández-Marchante, M. Zaiat, E. Gonzalez, M.A. Rodrigo, On the effects of ferricyanide as cathodic mediator on the performance of microbial fuel cells, Electrocatalysis 8 (2017) 59-66.

[30] B.E. Logan, et al., Microbial fuel cells: Methodology and technology, Environ. Sci Technol. 40 (17) (2006) 5181-5192.

[31] B.E. Logan, Exoelectrogenic bacteria that power microbial fuel cells, Nat. Rev. Microbiol. 7 (5) (2009) 375-381.

[32] R. Kumar, L. Singh, Z.A. Wahid, M.F.M. Din, Exoelectrogens in microbial fuel cells toward bioelectricity generation: a review, Int. J. Energy Res. 39 (8) (2015) 1048-1067.

[33] K.V. Krishna, S.V. Mohan, Selective enrichment of electrogenic bacteria for fuel cell application: Enumerating microbial dynamics using MiSeq platform, Bioresour. Technol. 213 (Aug. 2016) 146-154.

[34] C. Gao, A. Wang, W.-M. Wu, Y. Yin, Y.-G. Zhao, Enrichment of anodic biofilm inoculated with anaerobic or aerobic sludge in single chambered air-cathode microbial fuel cells, Bioresour. Technol. 167 (2014) 124-132.

[35] A.G. Capodaglio, D. Molognoni, S. Puig, M.D. Balaguer, J. Colprim, Role of operating conditions on energetic pathways in a microbial fuel cell, Energy Procedia 74 (2015) 728-735.

[36] F. Vicari, A. D'Angelo, A. Galia, P. Quatrini, O. Scialdone, A single-chamber membraneless microbial fuel cell exposed to air using Shewanella putrefaciens, J. Electroanal. Chem. 783 (2016) 268-273.

[37] J.M. Khudzari, J. Kurian, Y. Gariépy, B. Tartalowsky, G.S.V. Raghavan, Effects of salinity, growing media, and photoperiod on bioelectricity production in plant microbial fuel cells with weeping alkaligrass, Biomass Bioenergy 109 (2018) 1-9.

[38] I. Ieropoulos, J. Winfield, J. Greenman, Effects of flow-rate, inoculum and time on the internal resistance of microbial fuel cells, Bioresour. Technol. 101 (2010) $3520-3525$.

[39] B.E. Logan, M.J. Wallack, K. Kim, W. He, Y. Feng, P.E. Saikaly, Assessment of microbial fuel cell configurations and power densities, Environ. Sci. Technol. Lett. 2 (2015) 206-214.

[40] L.J.C. Jeuken, A.K. Jones, S.K. Chapman, G. Cecchini, F.A. Armstrong, Electrontransfer mechanisms through biological redox chains in multicenter enzymes, J. Am. Chem. Soc. 124 (20) (2002) 5702-5713.

[41] E. Marsili, J.B. Rollefson, D.B. Baron, R.M. Hozalski, D.R. Bond, Microbial biofilm voltammetry: direct electrochemical characterization of catalytic electrode-attached biofilms, Appl. Environ. Microbiol. 74 (23) (2008) 7329-7337.

[42] E. Labelle, D.R. Bond, Cyclic voltammetry for the study of microbial electron transfer at electrodes, Bioelectrochemical Syst. From Extracell. electron Transf. to Biotechnol. Appl. (2009) 137-152.

[43] E. Blanchet, E. Desmond, B. Erable, A. Bridier, T. Bouchez, A. Bergel, Comparison of synthetic medium and wastewater used as dilution medium to design scalable microbial anodes: Application to food waste treatment, Bioresour. Technol. 185 (2015) 106-115.

[44] E. Marsili, D.B. Baron, I.D. Shikhare, D. Coursolle, J.A. Gralnick, D.R. Bond, Shewanella secretes flavins that mediate extracellular electron transfer, Proc. Natl. Acad. Sci. U. S. A. 105 (10) (2008) 3968-3973.

[45] B. Saba, A.D. Christy, Z. Yu, A.C. Co, R. Islam, O.H. Tuovinen, Characterization and performance of anodic mixed culture biofilms in submersed microbial fuel cells, Bioelectrochemistry 113 (2017) 79-84. 